Starychenko, V., Levchenko, O., Zaika, Y., Holyk, L. (2021): Allelic state of Wx-genes and their relationship with granulometric structure of grain starch in collective samples of winter triticale. Agriculture and Forestry, 67 (3): $147-158$

DOI: 10.17707/AgricultForest.67.3.12

Vasyl STARYCHENKO', Olha LEVCHENKO', Yevhenii ZAIKA ${ }^{1}$, Lubov HOLYK

\title{
ALLELIC STATE OF WX-GENES AND THEIR RELATIONSHIP WITH GRANULOMETRIC STRUCTURE OF GRAIN STARCH IN COLLECTIVE SAMPLES OF WINTER TRITICALE
}

\section{SUMMARY}

The study was conducted to evaluate the collection of winter triticale (Triticosecale) by the polymorphism of alleles of $W x$ genes and the size of starch granules, as well as to establish the relationship between these traits. During research work were used PCR analysis, infrared spectrometry, light microscopy and different statistic methods. As result of study, it was found the presence of a wild-type allele of the $W x$-B1 gene in all studied samples of winter triticale, eight of which had a null-allele of the $W x$-A1 gene. The collection samples differed significantly in the size of the starch granules - the limits of variation ranged from 15.4 to $20.0 \mu \mathrm{m}$. It was determined that samples with low content of average sizes of starch granules were characterized by greater homogenity of granulometric structure. However, no significant correlations were found between the size of the starch granules, the starch content and the allelic state of the $W x$ A1 gene. After processing obtained data was selected collection specimens, that could be sources of valuable traits for new varieties suitable for processing into bioethanol.

Key words: bioethanol, amylopectin starch, sizes of starch granules, correlation analysis, sources of valuable traits.

\section{INTRODUCTION}

The aim of our study was to evaluate the collection of winter triticale (Triticosecale) by the polymorphism of $W x$ gene alleles and the size of starch granules of grain, to establish links between these traits. Main significance of this research is to identify collection specimens, that will be sources of valuable traits to create new varieties suitable for processing into bioethanol.

The main type of biofuel in the world is ethanol, the production of which is environmentally friendly and is relatively cheap (Chen-Guang et al., 2019;

\footnotetext{
${ }^{1}$ Vasyl Starychenko, Olha Levchenko (corresponding author: feniks1213@gmail.com), Yevhenii Zaika, Lubov Holyk, National Scientific Center "Institute of Agriculture of NAAS", 2-B Mashynobudivnykiv str., v. Chabany, Fastiv district, Kyiv region, 08162, UKRAINE

Notes: The authors declare that they have no conflicts of interest. Authorship Form signed online. 
Deepak end Vijay, 2019; Schneider et al., 2018; Shreyas et al., 2018; Sujit et al., 2019; Zabed et al., 2017). In Ukraine, cereals are mainly used as raw material for bioethanol production (Brei end Shchutskyi, 2016). Researchers have proven the prospects for the use of triticale grain for biofuel production, the advantages of which are primarily due to high yields and unpretentiousness to growing conditions (Cristina et al., 2016; Habtamu et al., 2018; McGoverin et al., 2011). In addition, triticale grain contains a lot of starch, which is characterized by increased enzymatic activity, which generally provides better cost-effectiveness of bioethanol production compared to other crops (Abdul et al., 2020; Klikocka et al., 2019; McKenzie et al., 2014; Rybalka, 2012). To further increase the volume and efficiency of biofuel production from triticale grains, it is necessary to create and introduce new varieties that will meet the modern requirements for suitability for processing into bioethanol (Dumbravăa et al., 2016; Grabovec et al., 2015; Kour. et al., 2019).

The yield of alcohol depends not only on the starch content in the grain, but also on the efficiency of its transformation into bioethanol, which is determined by the qualitative characteristics of starch. Amylopectin or waxy starch is characterized by high enzymeability, so cereals with starch of this type provide increased total yield of alcohol per unit mass and have advantages over use in the alcohol distillate industry (Yancheng et al., 2013). There are currently no triticale wax varieties among those introduced into production. Also, for triticale varieties suitable for processing into bioethanol, the granulometric structure of starch is an important indicator, because grain with small and aligned starch granules due to the larger area of reaction with enzymes has an accelerated fermentation process (Rybalka et al., 2013; Yaeel end Francisco, 2015; Yaeel, 2018). Thus, in the selection of triticale it is relevant and promising to create varieties with high content of amylopectin starch and with a fine and homogeneous composition of starch granules, which will increase the yield of bioethanol in grain processing (Rybalka et al., 2018; Zhao et al., 2009).

\section{MATERIAL AND METHODS}

The research was conducted during 2017-2019 at the National Scientific Center "Institute of Agriculture of NAAS", Ukraine. The soils of the fields belong to sod-medium-podzolic sandy loams. During the years of research, the temperature regime generally exceeded the value of the average long-term norm, and the amount of precipitation was characterized as arid.

The object of the study were 43 collection samples of winter triticale, which are represented by breeding numbers and varieties of selection of the Institute of Agriculture and varieties of foreign origin (Poland, Russia).

To determine the allelic state of the $W x$ gene by polymerase chain reaction (PCR), total DNA was isolated by CTAB + PVP. PCR was performed in an Applied Biosystems 2720 Termal Cycler using a set of GenPak ${ }^{\circledR P C R C o r e}$ reagents in $20 \mu \mathrm{l}$ of the reaction mixture containing 1 unit. Taq DNA polymerase 
(Somma et al., 2006; Stewart et al., 1993). When performing PCR analysis used the following primers:

$$
\begin{aligned}
& \text { gene Wx-A1 - Wx-A1F, } 5 \text {-ccccaaagcaaagcaggaaac-3`. } \\
& \text { Wx-A1R, } 5 \text { '-cggcgtcgggtccatagatc-3`. } \\
& \text { gene Wx-B1 - Wx-BDFL, } 5 \text {-ctggcctgctacctcaagagcaact-3`. } \\
& \text { Wx-BRC1, } 5 \text { '-ggttgcggttggggtcgatgac-3'. } \\
& \text { Wx-BFC, } 5 \text {-cgtagtaaggtgcaaaaaagtgccacg-3 . } \\
& \text { Wx-BRC2, } 5 \text {-acagccttattgtaccaagacccatgtgtg-3`. }
\end{aligned}
$$

Detection of PCR results was performed by horizontal electrophoresis in $1.2 \%$ agarose gel in TBE buffer in the presence of ethidium bromide, followed by visualization of the results in an ultraviolet transilluminator (Brody end Kern, 2004). The size of DNA fragments was evaluated for motility compared to control DNA markers.

For analysis to determine the size of starch granules, several grains from each sample were ground in a laboratory grinder and 20-30 mg of obtained flour was taken, followed by staining in $2 \mathrm{ml}$ of Lugol's iodine solution. The particle size distribution of the starch was examined by light microscopy in combination with digital analysis of the obtained images via a USB camera and ImageJ software (Wilson et al., 2006; Starychenko end Levchenko, 2019).

Determination of starch content in the grain was performed by infrared spectrometry on the device Infratec 1241. To confirm the statistical reliability of the obtained data were used various statistical methods using computer programs Excel 2007 and STATISTICA 8.

\section{RESULTS}

The collection of winter triticale was analyzed by the allelic state of wax genes by PCR. The controls were soft winter wheat varieties: Sofiyka wax variety and Oksana variety with ordinary starch (wild type).

According to the results of molecular genetic analysis of 16 samples the amplicon $652 \mathrm{bp}$, which corresponds to the null-allele of the $W x$-A1 gene, was found in breeding numbers triticale 229, 223 and 201 (tracks 7, 9 and 10) and in the control variety Sofiyka (15). Amplicons 495 and $176 \mathrm{bp}$ were found in all other samples of winter triticale and wheat control variety Oksana, which confirms the presence of a wild-type allele of the $W x$-A1 gene (Fig. 1). Among the following analyzed 29 collection samples, the presence of amplicon $652 \mathrm{bp}$ (null-allele $W x$-A1) was found only in varieties Lubomyr, Petrol, Poliskyi 7 and breeding numbers 141 and 153 .

The results of the analysis of the winter triticale collection by the allelic state of the $W x$-B1 gene showed that all triticale samples have an amplicon of 778 $\mathrm{bp}$, which indicates the presence of a wild-type allele of the $W x$-B1 gene.

To evaluate the collection of winter triticale by the granulometric size distribution of starch in the samples, the maximum, minimum and average sizes of starch granules were determined. The largest and smallest granules are usually present in small quantities, so an important characteristic of the particle size 
distribution is the average size of starch granules. It was found that the collection samples differed significantly in this indicator. Thus, in the variety Yasha the average grain size of starch was $15.4 \mu \mathrm{m}$, and in the variety Almaz $-20.0 \mu \mathrm{m}$ (Fig. 2).

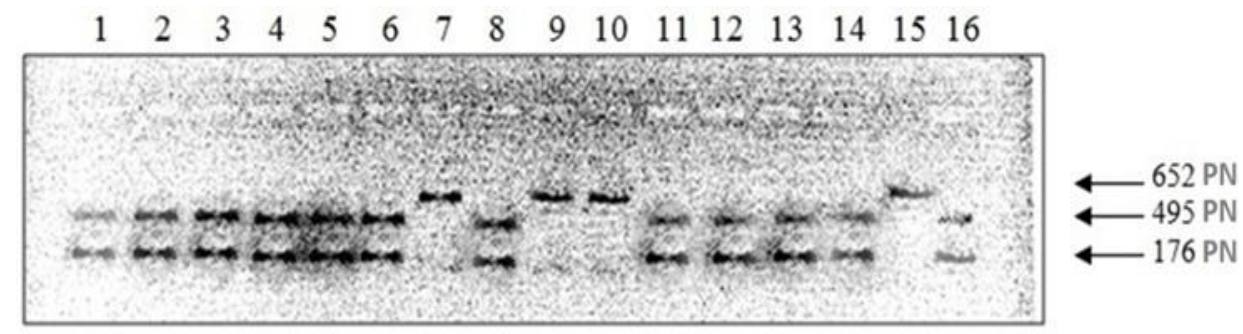

\section{$W x-\mathrm{Al}$}

Figure 1. Electrophoregram of PCR of $W x$-A1 gene products in collection samples of winter triticale and control varieties of winter wheat

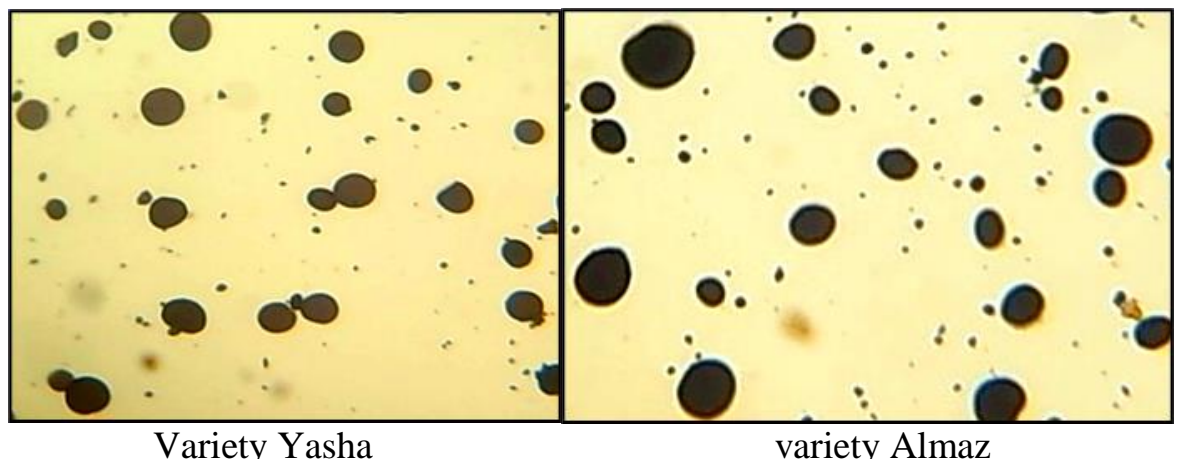

Figure 2. Granules of starch grain of winter triticale, microphoto at magnification $\mathrm{x} 45$

The largest average sizes of starch granules were determined in such samples as Maetok Polissya, 215, Dokuchaevske, Almaz (18.1-20.0 $\mu \mathrm{m})$, and the smallest - in samples Yasha, Mundo, 199, 141, $123(15.4-15.9 \mu \mathrm{m})$. The number of samples with average sizes of starch granules up to $16.0 \mu \mathrm{m}$ was $11.6 \%$ of the total collection, with a size from 16.1 to $17.0 \mu \mathrm{m}-41.8 \%$, from 17.1 to $18.0 \mu \mathrm{m}$ $-32,6 \%$. Groups of samples with average granule sizes of $18.1-19.0 \mu \mathrm{m}$ and $19.1-20.0 \mu \mathrm{m}$ accounted for 9.3 and $4.7 \%$ of the total collection.

According to the results of comparative evaluation of collection samples of triticale, no relationship was found between the size of starch granules and the content of starch in the grain. Such pairs of samples as Yasha and Mundo, 201 and 185, Petrol and Lubomyr, which were characterized by a close-sized particle size distribution, differed significantly in starch content (Fig. 3). The use of correlation analysis confirmed the lack of reliable relationships between these traits, which proves the possibility of selection work in the direction of 
simultaneously increasing the starch content and reducing the size of starch granules.

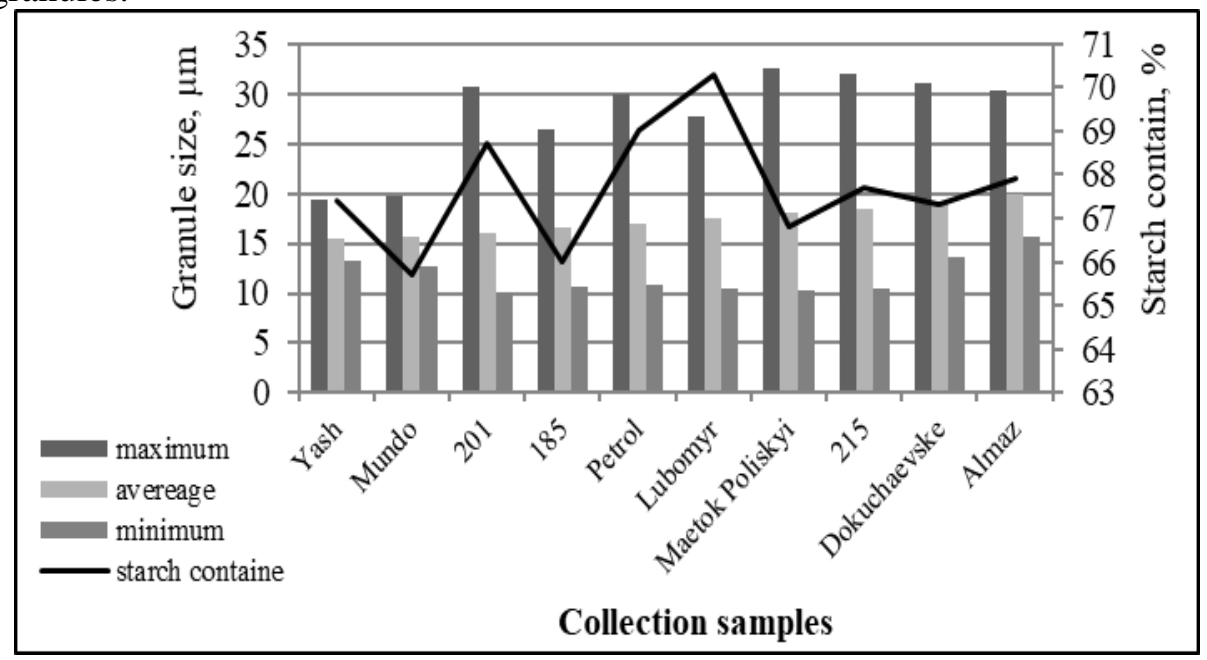

Figure 3. The size of starch granules and starch content in the grain of winter triticale collection samples, 2017-2019

Grain, the starch of which is homogeneous in granule size distribution, is more suitable for processing into bioethanol. Therefore, the analysis of starch samples is relevant not only for the size of its granules, but also for the alignment of the granule size distribution. It was found that in the varieties Yasha and Mundo starch consisted only of small granules up to $20.0 \mu \mathrm{m}$. Also, in the variety Poliskyi 7 and numbers 221, 201 and 199 revealed a relatively uniform particle size distribution of starch, where such granules ranged from 85.7 to $86.8 \%$. In general, the collection shows a tendency to link the alignment of the granule size distribution and the average size of starch granules. Samples with large indicators of medium size differed in their greater heterogenity compared to samples with small starch granules.

In the collection samples of winter triticale with null allele of the $W x$-A1 gene, a relatively small starch grain size was found, which averaged $16.5 \mu \mathrm{m}$ in these samples. In sample 141 the average size of starch granules was $15.9 \mu \mathrm{m}$, in samples 201, Poliskyi 7, 229, 223 and 153 it varied from 16.1 to $16.6 \mu \mathrm{m}$ and only in varieties Petrol and Lubomyr was 17.0 and $17.5 \mu \mathrm{m}$, respectively (Table 1). In varieties with the usual type of starch, such as Aristokrat, Solodyuk, Almaz and Dokuchaevske, the average granule size ranged from 18.0 to $20.0 \mu \mathrm{m}$, and the average for the collection of samples of triticale with wild-type $W x$-A 1 $17.3 \mu \mathrm{m}$. Therefore, an assumption was made about the tendency to decrease the size of starch granules in partially amylopectin forms of triticale with a null allele of the $W x$-A1 gene. 
To confirm the association of the allelic state of the $W x$-A1 gene with such quantitative traits as starch content and size of starch granules, a nonparametric method of calculating the Kendall correlation force was used (Khalafian, 2010).

Table 1. The average size of starch granules in collection samples of winter triticale with different allelic state of the Wx genes, 2017-2019

\begin{tabular}{|c|c|c|c|c|}
\hline \multirow[t]{2}{*}{$\begin{array}{l}\text { Collection } \\
\text { sample }\end{array}$} & \multirow[t]{2}{*}{$\begin{array}{c}\text { Country of } \\
\text { origin }\end{array}$} & \multicolumn{2}{|c|}{$\begin{array}{l}\text { Allelic state of the } W x \\
\text { genes }\end{array}$} & \multirow{2}{*}{$\begin{array}{c}\text { Average size of } \\
\text { starch granules, } \\
\mu \mathrm{m}\end{array}$} \\
\hline & & $W x-\mathrm{A} 1$ & $W x-\mathrm{B} 1$ & \\
\hline \multicolumn{5}{|c|}{ Samples with partially amylopectin type of starch } \\
\hline 141 & UKR & null-allele & wild type & 15,9 \\
\hline 201 & UKR & null-allele & wild type & 16,1 \\
\hline Poliskyi 7 & UKR & null-allele & wild type & 16,3 \\
\hline 229 & UKR & null-allele & wild type & 16,4 \\
\hline 223 & UKR & null-allele & wild type & 16,5 \\
\hline 153 & UKR & null-allele & wild type & 16,6 \\
\hline Petrol & UKR & null-allele & wild type & 17,0 \\
\hline Lubomyr & UKR & null-allele & wild type & 17,5 \\
\hline \multicolumn{5}{|c|}{ Samples with the usual type of starch } \\
\hline Arystokrat & UKR & null-allele & wild type & 18,0 \\
\hline Soloduk & UKR & null-allele & wild type & 18,0 \\
\hline Dokuchaevske & RUS & null-allele & wild type & 19,1 \\
\hline Almaz & RUS & null-allele & wild type & 20,0 \\
\hline
\end{tabular}

Table 2. Correlation of amylopectin type of starch controlled by the $W x$-A1 gene with starch content and size of starch granules in winter triticale

\begin{tabular}{|c|c|c|c|}
\hline Quantitati & signs & Year of the study & $W x$-A 1 alleles \\
\hline & & 2017 & $-0,07$ \\
\hline & & 2018 & 0,00 \\
\hline The starch conte & In the grain & 2019 & 0,02 \\
\hline & & average for 3 years & $-0,01$ \\
\hline & & 2017 & $-0,15$ \\
\hline & moximim & 2018 & $-0,09$ \\
\hline & maximum & 2019 & 0,01 \\
\hline & & average for 3 years & $-0,08$ \\
\hline & & 2017 & $-0,09$ \\
\hline The size of & Oyarom & 2018 & $-0,03$ \\
\hline starch granules & average & 2019 & $-0,10$ \\
\hline & & average for 3 years & $-0,06$ \\
\hline & & 2017 & $-0,06$ \\
\hline & minimum & 2018 & $-0,20 *$ \\
\hline & 11 & 2019 & $-0,21 *$ \\
\hline & & average for 3 years & $-0,19 *$ \\
\hline
\end{tabular}

* Correlations are significant at $\mathrm{p}<0.1$ 
There are no significant correlations between amylopectin-type starch and starch content, which is confirmed by the results of studies separately for 20172019 and on average for three years (Table 2). There was also no significant correlation between the allelic state of the $W x-\mathrm{A} 1$ gene and the maximum and minimum sizes of starch granules. Weak negative significant correlation (at $\mathrm{p}$ $<0.1)$ was observed with the average size of starch granules of the samples in 2018, 2019 and on average over three years. The revealed regularities prove the possibility of creating amylopectin varieties of triticale with small starch granules.

The graphic image clearly showed a different range of variation of the average sizes of starch granules in the collection samples of winter triticale in groups with wild-type and null-allele gene $W x$-A1 (Fig. 4).

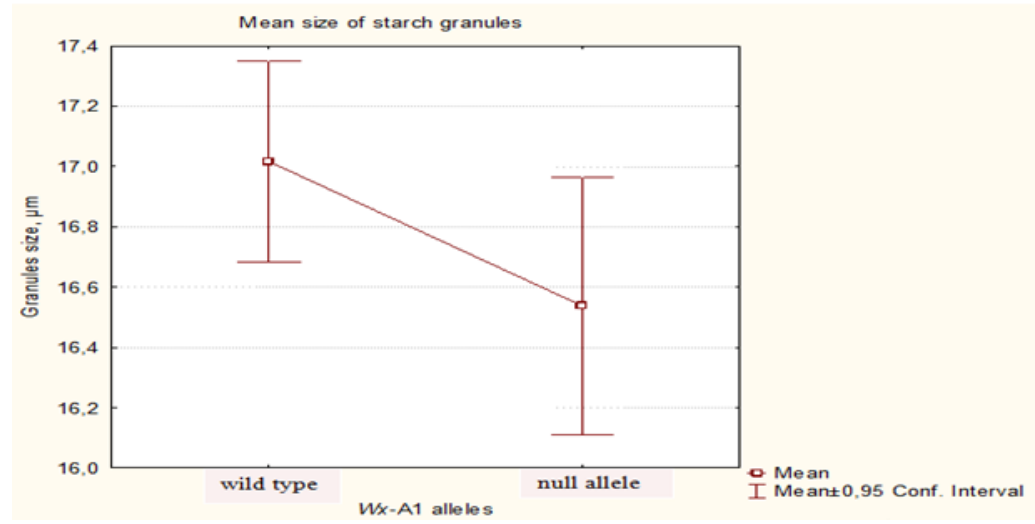

Figure 4. Ranges of distribution of average size of starch granules in winter triticale samples depending on the allelic state of the $W x$-A1 gene.

Null-allele genotypes had a smaller average granule size than samples with the wild-type allele of the $W x$-A1 gene, which was confirmed by a downward shift in the confidence interval in the group of samples with a partially amylopectival type of starch. The range of variation in the samples of the first group was $16.7-17.3 \mu \mathrm{m}$, and that of the second group was $16.1-16.9 \mu \mathrm{m}$. A larger range of variation was found in samples with a zero allele. Therefore, the dependence of the average size of starch granules on the allelic state of the $W x$ A1 gene was confirmed.

\section{DISCUSSION}

The consumption of fuel and energy is increasing in the world. But fossil sources are being depleted and not renewed. Therefore, it is important to use renewable biological fuels, one of which is bioethanol. The source for the production of bioethanol can be triticale grain (Mupondwa et al., 2018). The 
triticale varieties, that used for processing into bioethanol, should meet certain quality traits, including the content of starch and its quality.

Researchers have shown that the efficiency of processing grain into bioethanol also depends on the particle size distribution of starch (CornejoRamirez et al., 2015; Litvyak et al., 2018). Thus, according to Rybalka (Rybalka et al., 2013), Litvyak (Litvyak et al., 2018) and others, it is established that the best efficiency of transformation of starch into alcohol have varieties of crops with the highest percentage of fine granules. It was found that the starch granules of different cultures differ in size, shape and surface morphology. Starch grains of regular and irregular oval, round and multifaceted shape, the sizes of which vary from 0.5 to $60.0 \mu \mathrm{m}$ (Lindeboom et al., 2004), have been identified. A number of scientists from the United States, China, Ukraine and other countries have shown that the size of starch granules differs not only within genera and species, but also different varieties of the same culture (Seok-Ho et al., 2009; Zabolotets et al., 2018). There is evidence that the size of the granules and starch content in different crops are interdependent: at high values of the average size of starch grains, the starch content decreases, and at lower values, the percentage of starch increases (Zabolotets et al., 2018). According to the results of our research, a different genetically determined granulometric structure of starch in varieties and selection numbers of winter triticale was established. However, no relationship was found between the starch content in the grain and the size of the granules: collection samples with both high and low starch content were characterized by different particle size distribution.

Physico-chemical properties of amylopectin starch determine its advantages over conventional types of starch and the prospects for use in various industries, especially for the production of bioethanol (Chunyan et al., 2020a; Chunyan et al., 2020b; Fan, 2018; Yongfeng end Jay-lin, 2018).Varieties of wheat, corn, millet, sorghum and other crops with high amylopectin content have been obtained in the world, in which the synthesis of amylose is completely or partially blocked (Evžen end Dvořáček, 2017; Gago et al., 2014). To identify new valuable sources of starch wax, scientists are widely conducting research to identify polymorphism of $W x$ genes in different cultures using polymerase chain reaction (Morhun et al., 2015; Yuangen et al., 2013; Zhirnova et al., 2019). Three $W x$ genes have been identified in common wheat, each with several alleles (Juan and Carlos, 2016; Maningat et al., 2009; Zhao et al., 2009) - 77, 171, 185. According to Rybalka O. (Rybalka, 2015), in the triticale two recessive alleles of the genes $W x$-A1 and $W x$-B1 are localized in genome $\mathrm{A}$, in genome $\mathrm{B} W x$-alleles are not detected. According to the results of the analysis of the winter triticale collection, we isolated 8 samples with the presence of the $W x-\mathrm{A} 1$ gene in the genome of null-alleles.

According to the results of research by a number of scientists in determining the granule size distribution of different types of starch revealed a tendency to reduce the size of the granules in amylopectin varieties of wheat. Amylose content has been shown to be negatively correlated with the percentage 
of fine granules in the starch and positively correlated with the percentage of large ones (Wenyang et al., 2016; Xurun et al., 2015). Our studies found a decrease in the size of starch granules in partially amylopectin samples of winter triticale and found a significant negative correlation between the presence of the $W x$-A 1 allele in the samples and the average size of starch granules. In general, we can say that the identification of patterns of variation in the size of starch granules and polymorphism of the gene pool of cultures by allelic state of $W x$ genes require further in-depth study to use the results in creating a new source material with a combination of genotypes biofuels.

\section{CONCLUSIONS}

Eight samples (varieties Lubomyr, Petrol, Poliskyi 7 and breeding numbers $141,153,201,223,229)$ with a null-allele by the $W x$-A1 gene were isolated, which indicates a sufficient frequency of this allele in the gene pool of triticale common in Ukraine. It was found that all collection samples of winter triticale had a wild-type allele by the $W x$-B1 gene.

It was proven the genetic diversity of the winter triticale collection by the granulometric structure of starch has been brought. Limits of variability for the average size of the granules were set from $15.4 \mu \mathrm{m}$ in the variety Yasha to 20.0 $\mu \mathrm{m}$ in the variety Almaz. It has been established that from among the high indicators of the average size of starchy grains, a large heterogeneous stock of starch was grown.

A weak negative significant correlation (at $\mathrm{p}<0.1$, according to Kendall) was found between the presence of $W x$-A1 allele samples and the average size of starch granules, which confirmed the observed tendency of decreasing starch grain size in partially amylopectin samples of triticale.

Selected varieties Yasha and Mundo, characterized by fine and homogeneous granulometric structure of starch (average granule size 15.4 and $15.6 \mu \mathrm{m}$ ) and samples 141, 201, 229, 223, 153, Poliskyi 7 with partially amylopectin starch and medium granule size from 15.9 to $16.6 \mu \mathrm{m}$ are valuable sources for creating varieties for alcohol-distillate use.

\section{REFERENCES}

Abdul, M. \& Oseweuba, V., Jarien, D. (2020): Evaluation of Biorefining Scenarios for Advanced Fuels Production from Triticale Grain. Energy Fuels. Vol. 34 (9): 11003-11013. https://doi. org/10. 1021/acs. energyfuels. 0c01568

Brei, V. V. \& Shchutskyi, I. V. (2016): Bioethanol in Ukraine. Visn. Nac. Acad. NaukUkr. 6: 71-6. [In Ukrainian]. doi: 10. 15407/visn2016. 06. 071

Brody, J. R. \& Kern, S. E. (2004): History and principles of conductive media for standart DNA electrophoresis. Anal. Biochem. 333: 1-13. DOI: 10. 1016/j. ab. 2004. 05. 054. Please follow the instructions of the journal for stating the used literature.

Chen-Guang, L., Kai, L., Yuan, W. et al. (2019): Bioethanol: New opportunities for an ancient product. Advances in Bioenergy. Vol. 4: 1-34. https://doi. org/10. 1016/bs. aibe. 2018. 12. 002 
Chunyan, L., Dongdong, Zh., Ting, F. et al. (2020a): Structure and physicochemical properties of two waxy wheat starches. Food Chemistry. Vol. 318, 15: 126-152. https://doi. org/10. 1016/j. foodchem. 2020. 126492

Chunyan, Su, Ahmed, Bo, Kun, Zhao et al. (2020b): Changes in structural, physicochemical, and digestive properties of normal and waxy wheat starch during repeated and continuous annealing. Carbohydrate Polymers. Vol. 247: 166-175. https://doi. org/10. 1016/j. carbpol. 2020. 116675

Cornejo-Ramirez, Y. I., Cinco-Moroyoqui, F. J., Ramirez-Reyes, F. et al. (2015): Physicochemical characterization of starch from hexaploid triticale $(\times$ TriticosecaleWittmack) genotypes. CyTA - Journal of Food. 13 (3): 420-426. doi:10. 1080/19476337. 2014. 994565

Cristina, C., Francesco, P. \& Angelo, C. (2016): Triticale for bioenergy production. Agriculture and agricultural science procedia. 8: 609-616. https://doi. org/10. 1016/j. aaspro. 2016. 02.083

Deepak, K. \& Vijay, S. (2019): Bioethanol Production From Corn. Chemistry and Technology. Chapter 22: 615-631. https://doi. org/10. 1016/B978-0-12-8119716. 00022-X

Dumbravăa, M., Lenuţa, V., Epurea, I. et al. (2016): Yield and Yield Components at Triticale under Different Technological Conditions. Agriculture and Agricultural Science. 10: 94-103. https://doi. org/10. 1016/j. aaspro. 2016. 09. 023

Evžen, Š. \& Dvořáček, V. (2017): New processing and applications of waxy starch (a review): Journal of Food Engineering. Vol. 206: 77-87. https://doi. org/10. 1016/j. jfoodeng. 2017. 03. 006

Fan, Zhu. (2018): Relationships between amylopectin internal molecular structure and physicochemical properties of starch. Trends in Food Science \& Technology. V. 78: 234-242. https://doi. org/10. 1016/j. tifs. 2018. 05. 024Journal of Food Engineering. August. 206: 77-87. DOI: 10. 1016/j. jfoodeng. 2017. 03.006

Gago, F., Horváthová, V. \& Ondáš, V. (2014): Assessment of waxy and non-waxy corn and wheat cultivars as starch substrates for ethanol fermentation. Chemical Papers. 68(3): 300-7. https://doi. org/10. 2478/s11696-013-0454-1

Grabovec, A. I., Overchenko, M. B., Ignatova, N. I. \& Hrichikova G. N. (2015): Breeding of triticale for fermentation: results and problems. Legumes and cereals. 2 (14): 15-21. [In Russian].

Habtamu, A., Tadele, T. K., Twain, J. B. \& Xue-Feng, M. (2018): Triticale Improvement for Forage and Cover Crop Uses in the Southern Great Plains of the United States. Front Plant Sci. 9: 1130. DOI: 10. 3389/fpls. 2018. 01130

Juan, B. \& Carlos, G. (2016): Wheat waxy proteins: polymorphism, molecular characterization and effects on starch properties. Theoretical and Applied Genetics. Vol. 129, Issue 1: 1-16. DOI: 10. 1007/s00122-015-2595-9

Khalafian, A. A. (2010): Statistica 6. Statistical data analysis. Moscow, 528. [In Russian].

Klikocka, H., Kasztelan, A., Zakrzewska et al. (2019): The Energy Efficiency of the Production and Conversion of Spring Triticale Grain into Bioethanol. Agronomy. V. 9(8): 423. https://doi. org/10. 3390/agronomy9080423

Kour, D., A., Yadav, A. \& Gupta, A. (2019): Technologies for Biofuel Production: Current Development, Challenges, and Future Prospects. Prospects of Renewable Bioprocessing in Future Energy Systems. Biofuel and Biorefinery Technologies. V. 10: 1-50. https://doi. org/10. 1007/978-3-030-14463-0_1 
Lindeboom, N., Chang, P. \& Tyler, R. (2004): Analytical, Biochemical and Physicochemical Aspects of Starch Granule Size, with Emphasis on Small Granule Starches: A Review. Starch. V. 56, Issue3- 4: 89-99. https://doi. org/10. 1002/star. 200300218

Litvyak, V. V., Butrim, S. M., Kanarskij, A. V. \& Kanarskaya Z. A. (2018): Morphology and grain sizes of natural starch of different botanical origin. Bulletin of the University of Technology. 21 (3): 64-9. [In Ukrainian].

Maningat, C. C., Seib, P. A. \& Bassi, K. S. (2009): Wheat Starch: Production, Properties, Modification and Uses. Starch (Third Edition): Chemistry and Technology. Chapter 10: 441-510.

McGoverin, C. M., Snyders, F., Muller, N. et al. (2011): A review of triticale uses and the effect of growth environment on grain quality. Sci. food agric. 91: 1155-1165. doi: $10.1002 /$ jsfa. 4338

McKenzie, R. H., Bremer, E. \& Middleton, A. B. (2014): Agronomic practices for bioethanol production from spring triticale in Alberta. Canadian Journal of Plant Science. 94 (1): 15-22. DOI: 10. 4141/cjps2013-112

Morhun, B. V., Stepanenko, O. V., Stepanenko, A. L. \& Rybalka, O. I. (2015): Molecular genetic identification of Wx gene polymorphism in soft wheat hybrids using multiplex polymerase chain reactions. Plant Physiology And Genetics. 47(1): 25-35. [In Ukrainian].

Mupondwa E., Li X. \& Tabil L. (2018): Integrated bioethanol production from triticale grain and lignocellulosic straw in Western Canada. Industrial Crops and Products. V. 117: 75-87.

Rybalka, O. I. (2012): Triticale and energy. Grain (journal of the modern agroindustrialist): 9. [In Ukrainian]. URL: https://www. zerno-ua. com/journals/2012/sentyabr-2012-god/tritikale-i-energetika

Rybalka, O. I., Chervonis, M. V., Morgun, B. V. et al. (2013): Genetic and breeding criteria of crop cultivars production for ethanol distilling end-use. Physiology and biochemistry of cultivated plants. 45: 3-19. [In Ukrainian].

Rybalka, O. I., Morgun, V. V., Morgun, B. V. \& Pochinok, V. M. (2015): Agronomic potential and prospects of the tritica. Plant physiology and genetics. Vol. 47. No. 2: 95-111. [In Ukrainian].

Rybalka, O. I., Polishchuk, S. S. \& Morhun B. V. (2018): New directions in the selection of grain crops for grain quality. Visnyk ahrarnoinauky. 11 (788): 120-133. [In Ukrainian].

Schneider, R., Seidel, Jr., Fornasier, F. Et al. (2018): Bioethanol production from broken rice grains. Interciencia. V. 43: 846-851.

Seok-Ho, P., Wilson, D. \& Seabourn, W. (2009): Starch granule size distribution of hard red winter and hard red spring wheat: Its effects on mixing and breadmaking quality. Journal of Cereal Science. V. 49, Issue 1: 98-105. https://doi. org/10. 1016/j. jcs. 2008. 07. 011

Shreyas, N., Praful, B. \& Shadab, A. (2018): Biorefinery for fuels and platform chemicals. Bioethanol production: insight into past, present and future perspectives. Biofuels. Volume 9, Issue 2: 229-238. https://doi. org/10. 1080/17597269. 2017. 1334338

Somma, M., Querci, M., Jermini, M. \& Van den Eede, G. (2006): Extraction and purification of DNA. The analysis of food samples for the presence of genetically modified organisms. Luxembourg, 15-6. 
Stewart, C. N. Jr. \& Via, L. E. (1993): A rapid CTAB DNA isolation technique use for RAPID finger printing and other PCR applications. BioTechniques. 14(5): 748749.

Starychenko, V. M. \& Levchenko, O. S. (2019): Analysis of the starch granulometric composition of collection samples of winter triticale (TriticosecaleWittm.): Myronivskyi visnyk. 8: 33-45. [In Ukrainian].

Sujit, K., Mohanty, M. \& Swain, R. (2019): Bioethanol Production From Corn and Wheat. Food, Fuel, and Future. Chapter 3: 45-59. https://doi. org/10. 1016/B9780-12-813766-6. 00003-5

Wenyang, I., Suhui, Y., Xiaqing, S. et al. (2016): Starch granule size distribution from twelve wheat cultivars in east Chinas Huaibei region. Canadian Journal of Plant Science. 96(2): 176-82. https://doi. org/10. 1139/cjps-2015-0048

Wilson, J. D., Bechtel, D. B., Todd, T. C. \& Seib, P. A. (2006): Measurement of Wheat Starch Granule Size Distribution Using Image Analysis and Laser Diffraction. Cereal chemistry. 83 (3): 259-68. https://doi. org/10. 1094/CC-83-0259

Xurun, Y., Heng, Y., Jing, Z. et al. (2015): Comparison of endosperm starch granule development and physicochemical properties of starches from waxy and nonwaxy wheat. International Journal of Food Properties. 18: 2409-2421 https://doi. org/10. 1080/10942912. 2014. 980949

Yaeel, I. \& Francisco, J. (2015): Physicochemical characterization of starch from hexaploid triticale (x TriticosecaleWittmack) genotypes. Journal CYTA Journal of Food. 13 (3): 420-426. https://doi. org/10. 1080/19476337. 2014. 994565

Yaeel, I., Oliviert, M., Carmen, L., et al. (2018): The structural characteristics of starches and their functional properties. CyTA - Journal of Food. V. 16, issue 1: 10031017. https://doi. org/10. 1080/19476337. 2018. 1518343

Yancheng, H., Jiang, H. \& Blanco M. (2013): Characterization of Normal and Waxy Corn Starch for Bioethanol Production. Journal of Agricultural and Food Chemistry. V. 61: 379-386. DOI: 10. 1021/jf305100n

Yongfeng, A. \& Jay-lin, J. (2018): Understanding Starch Structure and Functionality. Starch in Food (Second Edition): Structure, Function and Applications. Ch. 3: 157-178. https://doi. org/10. 1016/B978-0-08-100868-3. 00003-2

Yuangen, L., Ganlin, Z. \& Yan, L. (2013): Identification of two novelwaxyalleles and development of their molecular markers in sorghum. Genome. 56 (5): 283-288. DOI:10. 1139/gen-2013-0047

Zabed, H., Suely, A., Boyce, A. N. \& Faruq, G. (2017): Bioethanol production from renewable sources: Current perspectives and technological progress. Renewable and Sustainable Energy Reviews. 71: 475-501. https://doi. org/10. 1016/j. rser. 2016. 12. 076

Zabolotets, A. A. \& Ermakov, A. I. (2018): Sizes and morphological features of grains of native starch of different botanical origin. Belarusian National Technical University. 24 (1): 245-255. [In Russian].

Zhao, R., Wu, X. \& Seabourn, B. W. (2009): Comparison of Waxy vs. NonwaxyWheats in Fuel Ethanol Fermentation. Cereal chemistry. 86 (2): 145-156. DOI: 10. 1094/CCHEM-86-2-0145

Zhirnova, I. A., Rysbekova, A. B., Diusibaeva, E. N. \& Seitkhozhaev, A. I. (2019): Assessment of the allelic state of $\mathrm{Wx}$ genes in the millet collection (Panicum miliaceum L.) based on molecular genetic markers. Bulletin of Karaganda University. Biology series. the medicine. 1 (93): 66-74. 